\title{
Does teachers' perceived corporate social responsibility lead to organisational citizenship behaviour? The mediating roles of job satisfaction and organisational identification
}

\begin{tabular}{|c|c|}
\hline \multicolumn{2}{|c|}{$\begin{array}{l}\text { Authors: } \\
\text { Kemal Cek } \\
\text { Serife Z. Eyupoglu }\end{array}$} \\
\hline \multicolumn{2}{|c|}{$\begin{array}{l}\text { Affiliations: } \\
{ }^{1} \text { Department of Business } \\
\text { Administration, Near East } \\
\text { University, Nicosia, Turkey }\end{array}$} \\
\hline \multicolumn{2}{|c|}{$\begin{array}{l}\text { Corresponding author: } \\
\text { Kemal Cek, } \\
\text { kemal.cek@neu.edu.tr }\end{array}$} \\
\hline \multicolumn{2}{|c|}{$\begin{array}{l}\text { Dates: } \\
\text { Received: } 01 \text { Mar. } 2019 \\
\text { Accepted: } 20 \text { Sept. } 2019 \\
\text { Published: } 18 \text { Nov. } 2019\end{array}$} \\
\hline \multicolumn{2}{|c|}{$\begin{array}{l}\text { How to cite this article: } \\
\text { Cek, K., \& Eyupoglu, S.Z. } \\
\text { (2019). Does teachers' } \\
\text { perceived corporate social } \\
\text { responsibility lead to } \\
\text { organisational citizenship } \\
\text { behaviour? The mediating } \\
\text { roles of job satisfaction and } \\
\text { organisational identification. } \\
\text { South African Journal of } \\
\text { Business Management 50(1), } \\
\text { a1481. https://doi.org/ } \\
\text { 10.4102/sajbm.v50i1.1481 }\end{array}$} \\
\hline \multicolumn{2}{|c|}{$\begin{array}{l}\text { Copyright: } \\
\text { ( ) 2019. The Authors. } \\
\text { Licensee: AOSIS. This wo } \\
\text { is licensed under the } \\
\text { Creative Commons } \\
\text { Attribution License. }\end{array}$} \\
\hline \multicolumn{2}{|l|}{ Read online: } \\
\hline 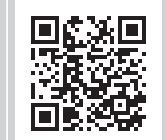 & $\begin{array}{l}\text { Scan this QR } \\
\text { code with your } \\
\text { smart phone or } \\
\text { mobile device } \\
\text { to read online. }\end{array}$ \\
\hline
\end{tabular}

Background: Corporate social responsibility (CSR) literature indicates that employees develop positive organisational behaviour towards their organisation when their organisation is perceived as being socially responsible. Such organisational behaviours include organisational citizenship behaviour (OCB), job satisfaction and organisational identity.

Objectives: The main objective of this study was to provide empirical evidence as to whether teachers' perceptions of their schools' CSR influence their OCB as well as to indicate the mediating role of organisational identification and job satisfaction in this relationship.

Setting: Corporate social responsibility is a valuable way for organisations to promote favourable employee behaviours.

Method: Data were collected through the use of a questionnaire from 260 teachers working at high schools in North Cyprus. Structural equation modelling was employed to test the hypotheses.

Results: The results of this study suggested that employees' perceptions of CSR positively influence their OCB when job satisfaction and organisational identification mediate the relationship.

Conclusion: The results of this study indicate that as long as employees are satisfied with their jobs and as long as they identify with their organisation, CSR favourably influences their voluntary behaviour, which in turn influences the overall performance of the organisation.

Keywords: Corporate social responsibility; organisational citizenship behaviour; job satisfaction; organisational identification; teachers.

\section{Introduction}

Corporate social responsibility (CSR) has become a concept that has a prominent dominance in the business ethics and sustainability literature. Financial crisis, scandals and the ever-growing competitive business environment makes it indispensable for all organisations to engage in environmental, social, ethical and normative tasks (Aizenman, Chinn, \& Ito, 2010; McWilliams, Siegel, \& Wright, 2006). Corporate social responsibility is considered as a key component of an organisation's image which determines the perceptions of their stakeholders such as employees and customers. Socially responsible activities are favourably perceived by employees and this enhances an ethical corporate climate (Sharma, 2019). Corporate social responsibility in developed countries has already become a crucial element for organisations. Similarly, in developing countries such as India, China and South Africa, governments are putting putting efforts into motivating organisations toward taking action against social issues (Sharma, 2019).

In recent years, CSR research has shifted from an antecedent-based focus to an outcome and process-based focus (Wang, Tong, Takeuchi, \& George, 2016). Scholars are placing more attention on the influence of CSR on organisational behaviour, organisational reputation, competitive advantage and sustainability rather than financial indicators such as profitability, stock performance and financial ratios (Snider, Hill, \& Martin, 2003; Turker, 2009). Consequently, an approach to CSR that focuses on behavioural outcomes is more relevant for the contemporary business climate. Researchers have focused on perceptions of employees as major stakeholders who contribute to organisational performance (Brammer, Millington, \& Rayton, 2007; Farooq, Payaud, Merunka, \& Florence, 2014; Jones, 2010; Turker, 2009). However, the foundations of CSR that affect employee behaviours have yet to be developed. 
The CSR literature provides some support for the fact that employees develop positive organisational behaviours toward their organisations when their organisations are perceived as socially responsible (Stites \& Michael, 2011; Valentine \& Fleischman, 2008). However, sufficient research does not exist to clearly answer the question of whether CSR contributes to organisational behaviours within educational organisations or lacks any impact. Such organisational behaviours include job satisfaction, identification, retention, motivation, commitment and organisational citizenship behaviours (OCB) (Caligiuri, Mencin, \& Jiang, 2013; Farooq et al., 2014; Rupp, Shao, Thornton, \& Skarlicki, 2013; Turker, 2009). According to Turan (2002), when the work experience and organisational climate become more engaging for teachers, their organisational performance increases. Therefore, it is evident that ethical climate and CSR initiatives of an organisation are critical elements that promote OCB in teachers (Karaköse, 2007). Organisational citizenship behaviour relates to the kind of behaviours that are not assigned to any individual by the formal structure of an organisation, and yet individuals exhibit these extra responsibilities voluntarily and with no expectation of reward (Geckil \& Tikici, 2015).

There is extensive research on OCB in business organisations; however, educational organisations have received much less attention (Zeinabadi \& Salehi, 2011). Teachers who display OCB are more involved in voluntary activities in support of their institutions. In addition, it has been implied that teachers demonstrate OCB by means of helping and guiding students, working extra hours and contributing to the functioning of their schools (DiPaola \& Hoy, 2005). Most recent research indicates that job satisfaction and organisational identification are proven to influence OCB and can be influenced by CSR (Barakat, Isabella, Boaventura, \& Mazzon, 2016; Farooq et al., 2014; Hameed, Riaz, Arain, \& Farooq, 2016; Kunda, Ataman, \& Behram, 2019). In this respect, this study contributes to the literature by examining the relationship between teachers' perceived CSR and their OCB via mediating effects of job satisfaction and organisational identification. Based on the social identity theory, teachers are expected to display OCB when they perceive positive CSR activities exercised within their institutions. In addition, according to the social exchange theory, teachers are expected to reciprocate the CSR activities of their school by displaying positive organisational behaviour. Therefore, drawing on both theories, a research framework was developed in which several contextual variables that were accessible from existing CSR and OCB literature were incorporated. In this study, a structural equation modelling analysis was applied to test the proposed relationship between teachers' perceived CSR and teachers' OCB as well as to test for the mediating effects of job satisfaction and organisational identification on this relationship.

\section{Theoretical background Corporate social responsibility}

Corporate social responsibility is a multifaceted concept. A generally accepted principle is to regard it as the implementation of socially responsible activities that are not governed by any law or authority or that are not carried out keeping in mind the interests of the organisations and that are in line with societal expectations (McWilliams et al., 2006). A widely accepted conceptualisation of CSR consists of CSR towards employees, CSR towards customers, CSR towards social and non-social stakeholders and CSR towards government (Turker, 2009). Moreover, a distinction has been made by scholars on these aspects and they are classified into two categories; namely, internal CSR and external CSR (Farooq, Rupp, \& Farooq, 2016). Internal CSR refers to an organisation's practices towards its employees' interests (Brammer et al., 2007; El Akremi, Gond, Swaen, De Roeck, \& Igalens, 2015; Farooq et al., 2016; Turker, 2009) and can be exemplified as involving the well-being of employees such as pursuing necessary human rights, providing a healthy and safe working environment, offering training and providing equal opportunities for every employee (Farooq et al., 2016; Gond, Kang, \& Moon, 2011; Turker, 2009). External CSR refers to an organisation's initiatives towards the interests of the environment, consumers and government (Brammer et al., 2007; Jones \& Rupp, 2016). This can be exemplified as participating in environmentally friendly practices, pursuing governmental obligations and contributing to the overall well-being of the society (Brammer et al., 2007).

Research has also indicated that CSR benefits organisations by providing an increased competitive advantage (McWilliams et al., 2006); increased financial performance (Orlitzky, 2005); positive consumer behaviours (Bhattacharya, Korschun, \& Sen, 2009); and increased corporate reputation (Fombrun, 2005). Literature on organisational behaviour suggests that employees' perceptions of CSR influence their behaviours and employees develop positive or negative attitudes depending on the CSR initiatives of their organisation (Stites \& Michael, 2011; Valentine \& Fleischman, 2008). It has been suggested that people tend to punish those who violate the stakeholders around them and appreciate those who act for the benefit of others around them (Cropanzano \& Rupp, 2008). Therefore, organisations' behaviour towards other internal and external stakeholders also influence employees' perceptions and behaviours (Cropanzano \& Rupp, 2008). Organisations' socially irresponsible activities may result in employees displaying unfavourable behaviour at the workplace (Hansen, Dunford, Boss, Boss, \& Angermeier, 2011). The CSR initiatives of organisations create an ethical climate within the organisation that promotes employees' positive organisational behaviours (Valentine \& Barnett, 2003) and may result in extra-role behaviours such as OCB (Hansen et al., 2011). In addition, Evans, Goodman and Davis (2010) claimed that employees who positively perceive their organisations' intentions to be socially responsible, respond by taking up extra responsibilities. Job satisfaction, OCB, motivation, lower absenteeism and increased commitment are some of the behaviours teachers show when they perceive their organisational climate as ethical (Shapira-Lishchinsky \& Rosenblatt, 2010). In the case of developing countries where the CSR initiatives are less formalised and philanthropic in 
nature; both internal and external CSR play an important role in affecting employees' organisational behaviours (Jamali \& Karam, 2018).

\section{Organisational citizenship behaviours}

Organisational citizenship behaviour refers to behaviour that employees develop towards the organisation of which they are a member (Geckil \& Tikici, 2015). Graham (1991) argues that OCB cannot possibly be limited to extra responsibilities and that on the contrary is a global term used to define all behaviours towards the organisation. In today's competitive world, organisations that flourish are those whose employees carry out duties beyond their assigned regular duties (Ali \& Waqar, 2013), because employees with a sense of citizenship work together in harmony and support each other's productivity (Sesen \& Basim, 2012). The antecedents and outcomes of OCB still require an in-depth research. Organ (1988) proposed a definition of OCB as individual behaviour that is discretionary, not directly or explicitly recognised by the formal reward system and that in the aggregate promotes the effective functioning of the organisation. By discretionary, it is meant that the behaviour is not an enforceable requirement of the role or the job description. According to Podsakoff, Podsakoff, MacKenzie, Maynes and Spoelma (2014), this definition emphasised the contribution of OCB to overall organisational performance and not necessarily the individual outcomes. Therefore, with OCB the emphasis is on the discretionary and on the beyond-the-call of duty attitudes and behaviours of employees (Podsakoff et al., 2014).

Even though numerous components of OCB have been presented within the literature (Organ, Podsakoff, \& MacKenzie, 2006), the Organ Theory provides considerably more accurate and widely accepted dimensions (Konovsky \& Organ, 1996; Podsakoff, MacKenzie, Moorman, \& Fetter, 1990). Organisational citizenship behaviour can be classified into five dimensions as conscientiousness, altruism, civic virtue, sportsmanship and courtesy (Podsakoff et al., 1990). In addition, Williams and Anderson (1991), described the concept of OCB as a two-dimensional construct, that is, as OCB towards individuals (OCB-I) and OCB towards organisations (OCB-O). Altruism and courtesy are classified as OCB-I whereas conscientiousness, civic virtue and sportsmanship are classified as OCB-O (Sesen \& Basim, 2012; Williams \& Anderson, 1991). In the case of schools, OCB-I includes teachers' behaviours towards fellow teachers, students and students' families. For instance, it is suggested that these behaviours include teachers helping their colleagues and students, participating in voluntary activities to help students and participating actively in school committees (DiPaola \& Hoy, 2005; Somech \& Bogler, 2005). Organisational citizenship behaviour towards organisations includes behaviours towards their organisations such as achieving organisational goals and objectives, for instance, participating in school activities, contributing to finding solutions of problems related with the school, performing efficiently and effectively at the school and contributing to the reputation of the school (DiPaola \& Hoy, 2005; Oplatka, 2006; Somech \& Bogler, 2005).

\section{Job satisfaction}

The concept of job satisfaction is defined as the physical, psychological and physiological aspects of the job that contribute to the job satisfaction of workers (Locke, 1969). Due to its relevance to the physical and mental well-being of the employee, job satisfaction has been widely studied in the management literature. Job satisfaction has also been found to be a significant contributor to several organisational outcomes such as performance, OCB, increased productivity, and lower absenteeism and turnover (Organ \& Ryan, 1995). In this sense, the factors that enhance job satisfaction of employees would be considered critical for any organisation. Furthermore, job satisfaction is considered a multifaceted concept that involves cognitive, affective and behavioural aspects. According to Gruenberg (1980), job satisfaction is the combination of subjective feelings that employees have towards their work. These feeling can be affected by wages, recognition, responsibilities, colleagues and work environment (Gruenberg, 1980). Moreover, job satisfaction can also be influenced by an organisation's CSR activities (Bauman \& Skitka, 2012). It is implied that positive or negative emotions can be observed within organisations with respect to CSR activities towards various stakeholders (Barakat et al., 2016).

Organisations that consider the interests of all stakeholders might observe a positive influence on their employees in terms of self-esteem, devotion, fulfilment and job satisfaction (Barakat et al., 2016). However, actions that can be regarded as socially irresponsible and those that are disturbing the interests of the stakeholders can have a negative influence on the employees in terms of dissatisfaction, degradation, disrespect and apprehension about their jobs (El Akremi et al., 2015; Onkila, 2015). Also, Greening and Turban (2000) claimed that organisations that actively engage in socially responsible activities become more attractive to prospective employees. Moreover, organisations that endorse organisational ethics and CSR experience greater job satisfaction among their current employees (De Roeck, Marique, Stinglhamber, \& Swaen, 2014). According to Bauman and Skitka (2012), CSR activities of organisations can lead to job satisfaction of employees in terms of security, safety, self-esteem, feeling of belongingness, fulfilment of social values and promotion of organisational purposes. It is argued that employees tend to perceive value and respond to the activities of organisations based on their own values and beliefs (Handelman, 2006). In that respect, social exchange theory can be used to explain the influence of CSR on employee behaviours. Through reciprocity, the social exchange theory assumes that the employees`organisational behaviours are influenced by the social exchanges between the organisation and the employees (Blau, 1964; Farooq et al., 2014). It is critical to have reciprocity between the two parties as the receiving party is expected to respond to the practices of the providing party (Gergen, 1969). In this sense, one party 
provides a benefit to the other based on voluntariness which invokes a sense of obligation to provide a benefit in return. The voluntariness aspect can be applied to the CSR which includes the voluntary activities of organisations towards their stakeholders. Therefore, perceived CSR of employees is expected to create a sense of obligation towards the organisation resulting in positive organisational behaviours such as commitment, trust, job satisfaction and OCB (Farooq et al., 2014).

Despite the importance of the relationship between CSR and job satisfaction, there have been inconclusive studies concerning this relationship (Bauman \& Skitka, 2012). It is indicated that the relationship is understudied even in the human resource literature which involves many aspects of organisational behaviours (Jiang, Lepak, Hu, \& Baer, 2012). It is proposed that employees' perceptions of CSR contribute to their behavioural attitudes such as job satisfaction (Rupp, Ganapathi, Aguilera, \& Williams, 2006). Therefore, it can be argued that perceived CSR can influence employees' job satisfaction, which can affect their OCB (Kunda et al., 2019). Barakat et al. (2016) claimed that job satisfaction leads to better job performance. The findings of this study, which focused on whether CSR positively influences job satisfaction, indicated that higher CSR perception led to greater job satisfaction. In this respect, it is expected that higher job satisfaction of teachers may contribute to employee behaviours such as OCB (Sesen \& Basim, 2012). Perceived CSR has been justified to have a significant relationship with job satisfaction (Barakat et al., 2016; Kunda et al., 2019; Sarfraz, Qun, Abdullah, \& Alvi, 2018; Valentine \& Fleischman, 2008) and job satisfaction with OCB (Organ \& Ryan, 1995; Williams \& Anderson, 1991).

It can be proposed that job satisfaction plays a mediatory role between CSR and OCB. Hence, it can be argued that employees' perceptions on CSR can enhance job satisfaction, which subsequently has an effect on OCB. Consequently, the following hypotheses are proposed:

H1a: Job satisfaction mediates the relationship between teachers' perceived internal CSR and OCB.

H1b: Job satisfaction mediates the relationship between teachers' perceived external CSR and OCB.

\section{Organisational identification}

Organisational identification is the degree to which members identify themselves with their organisation (Albert \& Whetten, 1985). Through organisational identification, employees consider the identities of their organisations as their own identity (Mael \& Ashforth, 1992). It has been argued that CSR initiatives of organisations create a positive image for the organisations (Farooq et al., 2014; Rupp \& Mallory, 2015). Employees' perception of the organisations' reputation and image affects their tendency to identify with the organisation. Through organisational identification, employees generate outcomes such as OCB, job satisfaction and increased job performance (Ashforth, Harrison, \& Corley, 2008). According to Aberson, Healy and Romero (2000), individuals strive for an attractive social identity; therefore, organisations should be more attractive in terms of reputation and image to benefit from organisational identification. Corporate social responsibility plays an important role in achieving organisational identification and it is a strategic tool for companies to enhance an attractive image. Corporate social responsibility initiatives increase the positive image of an organisation, resulting in employees feeling a sense of honour to be a part of the organisation. Research on the effect of CSR on employee behaviours through organisational identification is popular (Brammer et al., 2007; Hansen et al., 2011). However, there is still insufficient research on some aspects of employee behaviour in relation to OCB (He \& Brown, 2013; Farooq et al., 2014).

Corporate social responsibility initiatives can be seen as channels of communication with employees and other stakeholders. Therefore, stakeholders are likely to develop perceptions by responding to those initiatives and show organisational identification. Rupp and Mallory (2015) and Tyler and Blader (2003) suggest that a positive organisational identity will result in stronger organisational identification. Organisational identity enhanced through CSR initiatives will designate the degree to which employees develop organisational identification (Jones, 2010). In addition, previous research indicates that organisational identification of employees is also influenced by CSR initiatives through the lens of the social identity theory (Chun, Shin, Choi, \& Kim, 2013). According to Jones (2010), participation of organisations in voluntary and charitable activities enhances prestige and image, which in turn, affects employees' self-esteem. Prestige and image of an organisation should be appealing for the employees to identify themselves and therefore enhance their self-esteem and self-worth (Tyler \& Blader, 2003). Aguinis and Glavas (2013) claim that CSR creates a sense of purpose for employees. An organisation that acts for the benefit of all its stakeholders is likely to increase the salience of employees' organisational identification (Mael \& Ashforth, 1992). Moreover, organisational identification increases the tendency of employees to adopt organisational values as their own values and its objectives as their own objectives. Therefore, organisational identification could be a factor that increases employees' willingness to show discretionary behaviours such as OCB (Bartels, Peters, Jong, Pruyn, \& Molen, 2010). Organisations' CSR activities would reflect their values and contributions to the well-being of their employees and society, consequently motivating employees to feel a sense of belongingness towards their organisations and enhance organisational identification (Tyler \& Blader, 2003; Wu, Liu, Kwan, \& Lee, 2016). Thus, employees with higher levels of organisational identification tend to demonstrate more OCB (Wu et al., 2016).

Prior studies have shown that employees' perceptions of CSR influence their organisational identification (Carmeli, Gilat, \& Waldman, 2007; Jones, 2010). Organisational identification can contribute to favourable organisational behaviours such as OCB (Bartels et al., 2010). 
It is argued that CSR leads to organisational identification and helps employees to show extra-role and responsibility taking behaviours (Wang, Fu, Qiu, Moore, \& Wang, 2017). In this respect, employees who identify themselves with their organisation are likely to preserve their self-perception by involving in OCB (Evans \& Davis, 2014). Wang et al. (2017) found that organisational identification mediates the relationship between employees' perceived CSR and employees' turnover intention, job performance and helping behaviour. Employees who have positive CSR perceptions show organisational identification and engage in OCB (Bartels et al., 2010; Shen \& Benson, 2016). Although limited, previous research highlights the influence of external CSR on the employees' OCB (Graafland \& Zhang, 2014; Rupp et al., 2013). For instance, Rupp et al. (2013) found that perceived external CSR is a significant predictor of OCB. Furthermore, the mediatory role of organisational identification has been tested by previous scholars and a positive relationship has been found between perceived CSR and OCB through organisational identification (Evans \& Davis, 2014; Glavas \& Godwin, 2013; Graafland \& Zhang, 2014; Shen \& Benson, 2016). Employees' perceived CSR enhances their organisational identification, which subsequently promotes their organisational behaviours (Farooq et al., 2016). When the organisational identification is achieved, employees' tendency to show extra-role behaviours increases. Therefore, it can be suggested that perceived CSR contributes to the OCB through the mediation of organisational identity. Consequently, the following hypotheses are proposed:

H2a: Organisational identification mediates the relationship between teachers' perceived internal CSR and OCB.

$\mathrm{H} 2 \mathrm{~b}$ : Organisational identification mediates the relationship between teachers' perceived external CSR and OCB.

In light of the literature, the research model as well as the relationship between the variables are depicted in Figure 1.

\section{Methods}

\section{Data collection and respondent characteristics}

In this study, the sample consists of full-time teachers working in Nicosia, North Cyprus. North Cyprus is a developing

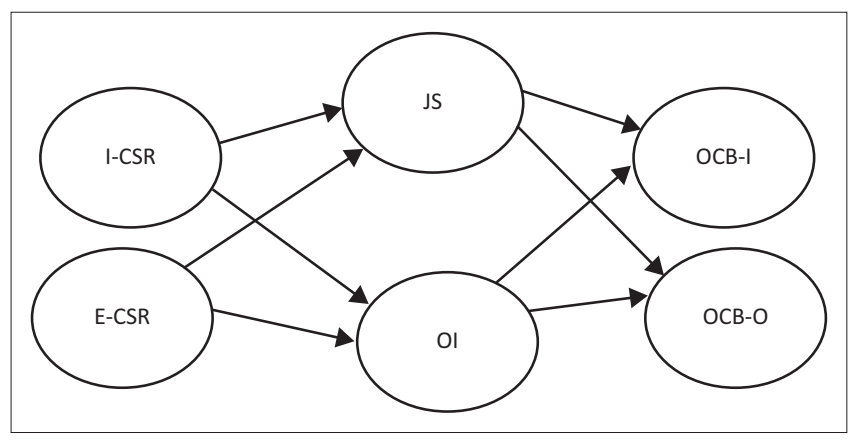

CSR, corporate social responsibility; E-CSR, external CSR; I-CSR, internal CSR; OI, organisational identity; JS, job satisfaction; OCB, organisational citizenship behaviour; OCB-I, OCB towards individuals; OCB-O, OCB towards organisation.

FIGURE 1: The theoretical model. country where studies on CSR and organisational behaviours are limited. Moreover, organisations' CSR initiatives in developing countries show differences compared to those in developed countries (Jamali \& Karam, 2018). Thus, a study in North Cyprus is expected to provide insights for other developing countries. Teachers who work in all schools within the Nicosia district were randomly selected to participate in this study. These educational institutions are involved in various CSR initiatives such as fundraising, providing emotional support to children in need; providing health support services to the children; participating in environment protection activities; supporting cultural and societal activities; providing information in order to promote awareness on the drug addiction to parents and the students; vocalising their opinions about the operation of governments and the measures they take in helping their employees sustain their well-being; and advocating for their overall development. Therefore, educational institutions and teachers play an important role within the society.

Upon receiving permission from the TRNC Ministry of Education, school administrators were contacted in order to explain the survey and to obtain approval for the implementation of the study. The respondents were randomly selected and the questionnaires were distributed to the respondents by the authors using a face-to-face technique. A cover letter was attached to the questionnaire indicating the aim, anonymity and confidentiality of the survey. The same procedure was carried out orally to reduce the social desirability bias (Chung \& Monroe, 2003). A box was placed at the secretary's room at each school to enhance anonymity. Respondents submitted their completed questionnaires into the box. The data were collected between 01 November 2018 and 31 December 2018. To eliminate the common method bias, the data were collected by allowing a 1-month lag between the data collection dates (Podsakoff, MacKenzie, Lee, \& Podsakoff, 2003). Out of the 400 questionnaires delivered, 260 were returned by the respondents. Furthermore, non-response bias was tested by comparing the demographics of teachers who filled out the questionnaires and the non-respondent teachers (Armstrong \& Overton, 1977). The $t$-test results showed no significant differences between them; therefore indicating that nonresponse bias was not an obstacle. Demographic profiles of the respondents are illustrated in Table 1. A total of $56.1 \%$ of the respondent teachers were female and $43.9 \%$ were male. A total of $6.1 \%$ of teachers were aged between 18 and 30, 28.5\% were aged between 31 and 40,40.4\% were aged between 41 and 50 and $25 \%$ were aged between 51 and 60 . A total of $75 \%$ of the participants held an undergraduate degree, $21 \%$ had a postgraduate degree and $4 \%$ held a doctorate degree. Teachers' years of experience ranged between 1 and 25 years in which $75 \%$ of the respondents had at least 15 years' experience.

\section{Measurement scales}

The questionnaire was separated into two parts; Part 1 consisted of demographic questions and Part 2 consisted of 
TABLE 1: Demographic profile of respondents.

\begin{tabular}{lcc}
\hline Variables & Frequency & $\%$ \\
\hline Gender & 146 & 56.1 \\
Female & 114 & 43.9 \\
Male & 260 & 100.0 \\
Total & & \\
Age & 16 & 6.1 \\
18-30 & 74 & 28.5 \\
$31-40$ & 105 & 40.4 \\
$41-50$ & 65 & 25.0 \\
$51-60$ & 260 & 100.0 \\
Total & & \\
Educational status & 195 & 75.0 \\
Undergraduate & 55 & 21.0 \\
Masters & 10 & 4.0 \\
Doctorate & 260 & 100.0 \\
Total & & \\
Experience & 5 & 1.9 \\
Less than 1 year & 18 & 6.9 \\
1-5 years & 12 & 4.7 \\
6-10 years & 30 & 11.5 \\
11-15 years & 195 & 75.0 \\
15 years and above & 260 & 100.0 \\
Total & & \\
\hline & & \\
\hline
\end{tabular}

CSR, OCB, job satisfaction and organisational identification scales. The questionnaires were pre-tested on 10 teachers and results indicated that there was no need for any modifications to the questionnaires.

The CSR scale, that was utilised to identify the respondent teachers' perceptions of their schools' CSR efforts, was developed by Turker (2009). The original scale consists of 17 items that are divided into four main parts: CSR to social and non-social stakeholders, customer and government which make up external CSR (E-CSR), and employees which make up internal CSR (I-CSR). Internal CSR is measured using five items with a Cronbach's alpha score of 0.71 and E-CSR is measured using 12 items with a Cronbach's alpha score of 0.89 . The Cronbach's alpha value for the total 17 items is measured as 0.88 . A few statements from the CSR scale are as follows: 'our organisation supports employees who want to acquire additional education' and 'our organisation implements flexible policies to provide a good work-life balance for its employees'. Respondents were asked to identify the degree of their agreement and disagreement with each of the 17 items on a five-point Likert scale extending from 1 (strongly disagree) to 5 (strongly agree).

The OCB scale, which was implemented in order to identify the respondent teachers' perception of their schools' CSR efforts, was developed by Podsakoff et al. (1990). The scale consists of 24 items that are divided into five sub-dimensions: altruism and courtesy, which make up OCB towards individuals (OCB-I); and conscientiousness, civic virtue and sportsmanship, which makeup OCB towards organisations (OCB-O). Organisational citizenship behaviour towards individuals is measured using 10 items with a Cronbach's alpha score of 0.85 and OCB-O is measured using 14 items with a Cronbach's alpha score of 0.85 . The Cronbach's alpha value for the overall OCB scale (total of 24 items) is measured as 0.89 . Some sample items from the OCB scale are as follows: 'I help others who have heavy workloads' and 'I attend and actively participate in company meetings'. Respondents were asked to identify the degree of their agreement and disagreement with each on the 24 items on a five-point Likert scale extending from 1 (strongly disagree) to 5 (strongly agree).

The job satisfaction scale, which aimed at identifying the respondent teachers' perception of their satisfaction levels in regards to their job on issues such as job security, recognition, wages and relationship with supervisors and colleagues, was developed by Macdonald and Maclntyre (1997). The Cronbach's alpha score of the scale is measured as 0.80 . Some sample items from the scale are as follows: 'I feel good about working at this organisation' and 'I feel secure about my job'.

The organisational identification scale, which aimed at determining to what degree the respondent teachers identify with their organisation, was developed by Mael and Ashforth (1992). The Cronbach's alpha score of the scale is measured as 0.79 . Some sample items from the scale are as follows: 'when someone criticizes my organisation it feels like a personal insult' and 'When someone praises this school, it feels like a personal compliment'.

\section{Ethical consideration}

This article followed all ethical standards for a research without direct contact with human or animal subjects.

\section{Results}

\section{Reliability, validity and common method bias}

The data were analysed using Statistical Package for Social Sciences (SPSS) 21 and Analysis of a Moment Structures (AMOS) 21.The data screening process consists of missing data, outliers, normality, linearity, homoscedasticity and multicollinearity. Initially, an exploratory factor analysis was conducted to test how the constructs load on the factors with Kaiser-Meyer-Olkin Test (KMO) being 0.843 and Bartlett's test of sphericity being significant $(p<0.01)$. The results showed that CSR items can be classified as external CSR and internal CSR and OCB items can be classified as OCB-I and OCB-O. Table 2 shows the factor correlation matrix and the square root of the average variance extracted (AVE) on the diagonal.

The control variables did not have a significant correlation with OCB-I and OCB-O. Petersitzke (2009) suggests that the non-significant control variables can affect the values of the significant variables in the model. Therefore, the control variables have not been included in the model.

Reliability, convergent validity and discriminant validity of the constructs were assessed using composite reliability (CR), 
TABLE 2: Factor correlation matrix

\begin{tabular}{|c|c|c|c|c|c|c|c|c|c|c|}
\hline Variables & 1 & 2 & 3 & 4 & 5 & 6 & 7 & 8 & 9 & 10 \\
\hline Gender & - & - & - & - & - & - & - & - & - & - \\
\hline Age & $0.14 *$ & - & - & - & - & - & - & - & - & - \\
\hline Education & -0.01 & $-0.13^{*}$ & - & - & - & - & - & - & - & - \\
\hline Experience & 0.01 & $0.68 * *$ & $-0.18 * *$ & - & - & - & - & - & - & - \\
\hline E-CSR & 0.05 & -0.05 & 0.05 & -0.07 & 0.84 & - & - & - & - & - \\
\hline I-CSR & 0.02 & -0.04 & 0.09 & -0.10 & $0.60 * *$ & 0.75 & - & - & - & - \\
\hline OI & 0.07 & 0.01 & 0.13 & -0.10 & $0.32 * *$ & $0.46 * *$ & 0.74 & - & - & - \\
\hline JS & -0.03 & -0.00 & 0.12 & -0.10 & $0.23 * *$ & $0.41 * *$ & $0.34 * *$ & 0.73 & - & - \\
\hline OCB-I & -0.09 & 0.15 & -0.01 & 0.06 & 0.01 & 0.03 & $0.20 * *$ & $0.41 * *$ & 0.74 & - \\
\hline OCB-O & -0.02 & 0.05 & 0.01 & -0.06 & 0.01 & -0.04 & $0.22 *$ & $0.45 * *$ & $0.55^{* *}$ & 0.72 \\
\hline
\end{tabular}

$\mathrm{M}$, mean score; CSR, corporate social responsibility; E-CSR, external CSR; I-CSR, internal CSR; OI, organisational identity; JS, job satisfaction; OCB, organisational citizenship behaviour; OCB-I, OCB towards individuals; OCB-O, OCB towards organisation.

$*, p<0.05 ; * *, p<0.01$.

AVE and maximum shared variance (MSV). According to Hair, Black, Babin and Anderson (2014), AVE should be higher than 0.50 for convergent validity; CR should be higher than 0.70 for reliability and to achieve discriminant validity MSV should be lower than AVE. Table 3 shows the measures that are reliable and meet the validity criteria and the mean values of the variables. It is observed that mean values of internal CSR and external CSR are considerably low. This may indicate that teachers' perceptions were low regarding their organisations' CSR activities. The mean scores of the mediators were higher than the CSR perceptions as job satisfaction and organisational identification showed a mean score of 3.76 and 3.60 respectively. Lastly, OCB-I and OCB-O showed mean scores as 4.40 and 4.13, respectively, which implies that teachers' OCB were higher than other variables. Furthermore, Podsakoff, MacKenzie and Podsakoff (2011) suggest that common method variance, which is the loading of manifest variables' variance on a single latent factor, could be a problem for self-reported measurement constructs. According to Chang, Van Witteloostuijn and Eden (2010), multiple methods should be used to ensure that common method bias is not an obstacle. Therefore, the common method bias was tested by using both the common latent factor test using AMOS which showed that the common method variance is below the threshold (3\%) and the Harmans's single factor test using SPSS which showed that the factor did not account for substantial variance $(19.3 \%)$. The results indicated that the common method bias is not an obstacle for this study.

Confirmatory factor analysis (CFA) was conducted to establish construct validity using AMOS 21. The factor loadings of the constructs are shown in Table 3. The model's goodness of fit indices were evaluated using: the comparative fit index (CFI), the Tucker-Lewis index (TLI), the chi-square mean/degree of freedom (CMIN/df), the root mean square error (RMSEA) and the standardised root mean square residual (SRMR). According to $\mathrm{Hu}$ and Bentler (1999) and Hair et al. (2014), a good model fit should have CFI and TLI above 0.90, RMSEA below 0.05 and SRMR below 0.09 .

The first CFA model (one-factor model) shows a poor fit which consists of CSR, OCB, JS and organisational identification as a single factor. The second model (five-factor model) includes the internal CSR, external CSR, OCB-I,
OCB-O and the organisational identification shows a good model fit $(\mathrm{CMIN} / \mathrm{df}=1.530, p<0.05, \mathrm{CFI}=0.95, \mathrm{TLI}=0.94$, RMSEA $=0.05$, SRMR $=0.05$ ). The third model (five-factor model) includes the internal CSR, external CSR, OCB-I, OCB-O and the job satisfaction also shows a good model fit $(\mathrm{CMIN} / \mathrm{df}=1.331, p<0.05, \mathrm{CFI}=0.97, \mathrm{TLI}=0.97, \mathrm{RMSEA}=$ 0.04, SRMR $=0.05$ ). The fourth model (six-factor model) includes all the variables including internal CSR, external CSR, job satisfaction, organisational identification, OCB-I and OCB-O and shows a good model fit $(\mathrm{CMIN} / \mathrm{df}=1.325$, $p<0.05, \mathrm{CFI}=0.97, \mathrm{TLI}=0.96, \mathrm{RMSEA}=0.04, \mathrm{SRMR}=0.05)$. In addition, the Chi-square difference test was conducted to compare the model fits (Wang et al., 2017). The results showed that the six-factor model is superior to the five-factor model consisting of internal CSR, external CSR, OCB-I, OCB-O and the organisational identification $\left(\Delta \chi^{2}=54\right.$ 532, $\Delta d f=4$, $p<0.001)$ and the five-factor model consisting of internal CSR, external CSR, OCB-I, OCB-O and the job satisfaction $\left(\Delta \chi^{2}=4888, \Delta d f=4, p<0.001\right)$.

\section{Hypothesis testing}

Initially, a model was tested where a direct path without the mediators from the internal and external CSR to teachers' OCB-I and OCB-O was added. The direct effect of internal and external CSR was found not to be significant $(p>0.05)$. Therefore, this suggests that the mediated model is superior to the direct model (Raykov \& Marcoulides, 1999). The estimated path coefficients are shown in the Table 4.

The proposed model could explain $17 \%$ of the variance in job satisfaction, $28 \%$ of the variance in organisational identification, $18 \%$ of variance in OCB-I and $30 \%$ of the variance in OCB-O. Moreover, the results showed that the direct effect of internal CSR is positive on job satisfaction $(b=0.48, p<0.01)$ and organisational identification $(b=0.44$, $p<0.01)$. However, external CSR did not show a significant relationship with the mediators. Job satisfaction showed a positive effect on OCB-I $(b=0.41, p<0.01)$ and OCB-O ( $b=0.54, p<0.01)$. Organisational identification failed to show a significant effect on OCB-I, but showed a significant effect on OCB-O $(b=0.23, p<0.05)$. To test the indirect and mediation effects of job satisfaction and organisational identification, 95\% bias-corrected bootstrapped confidence intervals $(N=5000)$ were employed. 
TABLE 3: Scale items, construct means standard loadings, reliability and validity measures.

\begin{tabular}{|c|c|c|c|}
\hline Construct & Factors & Standard loading & Measure \\
\hline \multirow[t]{9}{*}{ I-CSR } & CSR1 & $0.705^{*}$ & - \\
\hline & CSR2 & $0.761 *$ & - \\
\hline & CSR3 & $0.736^{*}$ & - \\
\hline & CSR4 & $0.761 *$ & - \\
\hline & CSR5 & $0.705^{*}$ & - \\
\hline & Mean & - & 3.36 \\
\hline & Composite reliability & - & 0.86 \\
\hline & Average variance extracted & - & 0.56 \\
\hline & Maximum shared variance & - & 0.35 \\
\hline \multirow[t]{8}{*}{$\mathrm{E}-\mathrm{CSR}$} & CSR5 & $0.839 *$ & - \\
\hline & CSR6 & $0.835^{*}$ & - \\
\hline & CSR7 & $0.853 *$ & - \\
\hline & CSR8 & $0.805^{*}$ & - \\
\hline & Mean & - & 3.08 \\
\hline & Composite reliability & - & 0.90 \\
\hline & Average variance extracted & - & 0.70 \\
\hline & Maximum shared variance & - & 0.35 \\
\hline \multirow[t]{7}{*}{ JS } & JS1 & $0.592 *$ & - \\
\hline & JS2 & $0.816^{*}$ & - \\
\hline & JS3 & $0.751 *$ & - \\
\hline & Mean & - & 3.76 \\
\hline & Composite reliability & - & 0.77 \\
\hline & Average variance extracted & - & 0.53 \\
\hline & Maximum shared variance & - & 0.28 \\
\hline \multirow[t]{7}{*}{ OI } & ID1 & $0.615^{*}$ & - \\
\hline & ID2 & $0.898 *$ & - \\
\hline & ID3 & $0.691 *$ & - \\
\hline & Mean & - & 3.60 \\
\hline & Composite reliability & - & 0.78 \\
\hline & Average variance extracted & - & 0.55 \\
\hline & Maximum shared variance & - & 0.22 \\
\hline \multirow[t]{7}{*}{ OCB-I } & OCB1 & $0.707 *$ & - \\
\hline & OCB2 & $0.744^{*}$ & - \\
\hline & OCB3 & $0.725^{*}$ & - \\
\hline & Mean & - & 4.40 \\
\hline & Composite reliability & - & 0.78 \\
\hline & Average variance extracted & - & 0.55 \\
\hline & Maximum shared variance & - & 0.30 \\
\hline \multirow[t]{10}{*}{ OCB-O } & OCB4 & $0.568^{*}$ & - \\
\hline & OCB5 & $0.653^{*}$ & - \\
\hline & осB6 & $0.619 *$ & - \\
\hline & OCB7 & $0.796 *$ & - \\
\hline & OCB8 & $0.737^{*}$ & - \\
\hline & осв9 & $0.764 *$ & - \\
\hline & Mean & - & 4.13 \\
\hline & Composite reliability & - & 0.86 \\
\hline & Average variance extracted & - & 0.51 \\
\hline & Maximum shared variance & - & 0.30 \\
\hline
\end{tabular}

$\mathrm{M}$, mean score; CSR, corporate social responsibility; E-CSR, external CSR; I-CSR, internal CSR; $\mathrm{OI}$, organisational identity; JS, job satisfaction; OCB, organisational citizenship behaviour; OCB-I, OCB towards individuals; OCB-O, OCB towards organisation.

$*, p<0.01$.

Hypothesis $1 \mathrm{a}$ and $1 \mathrm{~b}$ proposed the indirect effect of internal and external CSR on OCB-I and OCB-O via job satisfaction. The results showed that the link between internal CSR and OCB-I and OCB-O is mediated by job satisfaction $(b=0.16$ and $b=0.10, p<0.01$ ), fully supporting hypothesis 1a. External CSR did not show a significant effect on OCB-I and OCB-O via job satisfaction, and hypothesis $1 \mathrm{~b}$ was not supported. Hypothesis $2 \mathrm{a}$ and $2 \mathrm{~b}$ proposed that organisational
TABLE 4: Mediation analysis results.

\begin{tabular}{|c|c|c|c|}
\hline \multirow[t]{2}{*}{ Mediation paths } & \multirow[t]{2}{*}{ Coefficients } & \multicolumn{2}{|c|}{$\mathrm{BC} 95 \% \mathrm{Cl}$} \\
\hline & & Lower & Upper \\
\hline $\mathrm{I}-\mathrm{CSR} \rightarrow \mathrm{JS} \rightarrow \mathrm{OCB}-\mathrm{O}$ & $0.16^{* *}$ & 0.063 & 0.296 \\
\hline I-CSR $\rightarrow$ JS $\rightarrow$ OCB-I & $0.10 * *$ & 0.044 & 0.198 \\
\hline $\mathrm{I}-\mathrm{CSR} \rightarrow \mathrm{OI} \rightarrow \mathrm{OCB}-\mathrm{O}$ & $0.04 *$ & 0.000 & 0.127 \\
\hline $\mathrm{I}-\mathrm{CSR} \rightarrow \mathrm{OI} \rightarrow \mathrm{OCB}-\mathrm{I}$ & $0.03 *$ & 0.009 & 0.107 \\
\hline $\mathrm{E}-\mathrm{CSR} \rightarrow \mathrm{JS} \rightarrow \mathrm{OCB}-\mathrm{O}$ & -0.02 & -0.082 & 0.027 \\
\hline $\mathrm{E}-\mathrm{CSR} \rightarrow \mathrm{JS} \rightarrow \mathrm{OCB}-\mathrm{I}$ & -0.01 & -0.055 & 0.016 \\
\hline $\mathrm{E}-\mathrm{CSR} \rightarrow \mathrm{OI} \rightarrow \mathrm{OCB}-\mathrm{O}$ & 0.01 & -0.004 & 0.040 \\
\hline $\mathrm{E}-\mathrm{CSR} \rightarrow \mathrm{OI} \rightarrow \mathrm{OCB}-\mathrm{O}$ & 0.01 & -0.003 & 0.031 \\
\hline \multicolumn{4}{|l|}{ Regression weights } \\
\hline $\mathrm{I}-\mathrm{CSR} \rightarrow \mathrm{JS}$ & $0.48 * *$ & - & - \\
\hline $\mathrm{I}-\mathrm{CSR} \rightarrow \mathrm{OI}$ & $0.44 * *$ & - & - \\
\hline $\mathrm{E}-\mathrm{CSR} \rightarrow \mathrm{JS}$ & -0.09 & - & - \\
\hline $\mathrm{E}-\mathrm{CSR} \rightarrow \mathrm{OI}$ & 0.08 & - & - \\
\hline $\mathrm{JS} \rightarrow \mathrm{OCB}-\mathrm{O}$ & $0.54 * *$ & - & - \\
\hline$J S \rightarrow O C B-I$ & $0.41 * *$ & - & - \\
\hline $\mathrm{OI} \rightarrow \mathrm{OCB}-\mathrm{O}$ & $0.23 *$ & - & - \\
\hline $\mathrm{OI} \rightarrow \mathrm{OCB}-\mathrm{I}$ & 0.16 & - & - \\
\hline \multicolumn{4}{|l|}{ R-squared } \\
\hline JS (\%) & 17 & - & - \\
\hline OI (\%) & 28 & - & - \\
\hline OCB-O (\%) & 30 & - & - \\
\hline OCB-I (\%) & 18 & - & - \\
\hline
\end{tabular}

Note: $\mathrm{CMIN} / d f=1.267 ; \mathrm{CFI}=0.97 ; \mathrm{TLI}=0.97 ; \mathrm{RMSEA}=0.03 ; \mathrm{SRMR}=0.05$

$\mathrm{CMIN} / d f$, chi-square mean/degree of freedom; CFI, comparative fit index; TLI, Tucker-Lewis index; RMSEA, root-mean square error; SRMR, standardised root mean square residual; CSR, corporate social responsibility; E-CSR, external CSR; I-CSR, internal CSR; OI, organisationa identity; JS, job satisfaction; OCB, organisational citizenship behaviour; OCB-I, OCB towards individuals; OCB-O, OCB towards organisation.

$*, p<0.05 ; * *, p<0.01$

identification would mediate the relationship between internal and external CSR and OCB-I and OCB-O. The indirect effect of teachers' perceptions of internal CSR on OCB-I via organisational identification was positive at $95 \%$ confidence interval $(b=0.03, p<0.05)$. In addition, the indirect effect of teachers' perceptions of internal CSR on OCB-O via organisational identification was positive at $95 \%$ confidence interval $(b=0.04, p<0.05)$. Therefore, hypothesis $2 \mathrm{a}$ was fully supported. Hypothesis $2 b$ stated that organisational identification would mediate the link between external CSR and OCB-I and OCB-O. This hypothesis was not supported. Hence, the indirect effect of internal CSR on OCB was significant. However, the indirect effect of external CSR on OCB was found not to be significant.

\section{Discussion and conclusion}

This study explored the relationship between CSR and OCB though the multiple mediation of job satisfaction and organisational identification based on the social identity theory and the social exchange theory. The findings implied that the positive effect of internal CSR on OCB is not observed directly, but it affects OCB via job satisfaction and organisational identification. Internal CSR was found to be a significant predictor of OCB-I and OCB-O through job satisfaction and organisational identification whereas the effect of external CSR was non-significant. A major finding of this study is that external CSR did not show a significant influence on OCB-I and OCB-O. This implies that internal CSR plays an important role on OCB by establishing job satisfaction and organisational identification. 
The findings justify the social identity and social exchange theory which implies that identification and reciprocation should exist to observe OCB. In other words, job satisfaction and organisational identification should be established within the organisation. Employees who identify themselves with their organisation engage in OCB (Brammer, He, \& Mellahi, 2015; Hameed et al., 2016). Schools that take care of their employees' welfare might develop a reputation as a socially responsible organisation (Hofman \& Newman, 2014). Thus, enhancement of teachers' self-esteem can yield organisational identification. Teachers who develop identification will be more likely to make an extra effort to participate in OCB (Carmeli et al., 2007). Moreover, through the lens of the social exchange theory, employees who have a positive perception of CSR by their organisation tend to be satisfied with their jobs and engage in OCB. Favourably perceived CSR might create job satisfaction and an obligation to respond by displaying OCB. This finding supports studies that have shown that perceived CSR towards employees can lead to increased job performance (Eisenberger, Armeli, Rexwinkel, Lynch, \& Rhoades, 2001; Organ et al., 2006). External CSR is found to be an insignificant predictor of OCB. This implies that when considering $\mathrm{OCB}$ that are related to employees' behaviours within the workplace, the activities of organisations towards social and non-social stakeholders as external stakeholders do not have a significant effect on employees' behaviours within the workplace. Furthermore, CSR studies conducted in a developing country such as North Cyprus may imply that teachers can be locally oriented individuals. Therefore, the findings support Farooq et al.'s (2016) arguments that employees with local orientation background are more likely to develop identification from internal CSR rather than external CSR. This indicates that teachers might have individualist behaviours that posit that one's own welfare is more important than others' (Farooq et al., 2016; Markus \& Kitayama, 1991).

Prior CSR research related to educational institutions focused on higher education in developed countries; however, the effect of perceived CSR on school performance remains understudied in developing countries. In addition, the generalisability of findings in the context of developed countries is an issue for developing countries (Idemudia, 2011; Jamali \& Karam, 2018). This study has several implications for practitioners and managers. Teachers as employees have been ignored by previous organisational studies (Oplatka, 2006). Therefore, this study provides substantial insight for educational institutions, managers and teachers. Organisational performance cannot be achieved solely through in-role requirements and extra-role behaviours such as OCB are required to achieve sustainable organisational performance (Somech \& Bogler, 2005). Schools should have teachers who are willing to display OCB and contribute to their organisations and help their colleagues (DiPaola \& Hoy, 2005). The findings indicate that perceived internal CSR, which is CSR towards employees, has a positive indirect effect on OCB through job satisfaction and organisational identification. Therefore, it is crucial for organisations to initiate CSR activities that consider the welfare of their employees. The importance of enhancing job satisfaction and organisational identification at the workplace has also been supported. The results implied that without job satisfaction and organisational identification as mediators, the direct effect of internal CSR would be insignificant on OCB. Thus, it is necessary to enhance job satisfaction and identification among teachers to observe the positive effects on OCB.

This study contributes to the CSR and organisational behaviour literature by providing insights into the mediation effects of job satisfaction and organisational identification. Although a growing body of research has been conducted on the effects of perceived CSR on various organisational performance variables, the mediation effects still require in-depth research. Another unique contribution of this study is that this is the first study known to evaluate teachers as employees under this context. The findings provide evidence of the indirect effects of perceived internal CSR on OCB.

\section{Limitations and suggestions}

This study has several limitations. Firstly, the sample does not represent all teachers in North Cyprus. It only comprises of school teachers employed in Nicosia. Therefore, this limits the generalisability of the findings to a larger population. Secondly, the data shares the limitations associated with the cross-sectional data that limits the causality tests. Thus, a longitudinal research design would yield better results. In addition, the roles of different mediating variables such as organisational commitment, justice, trust and democracy each carry a potential for further research.

\section{Acknowledgements}

This work is based on the doctorate degree dissertation of K.C. entitled 'The effects of corporate social responsibility on the organisational citizenship behaviour of school teachers: the role of organisational trust, identity and job satisfaction', which will be submitted (planned date of completion: December 2019) to the Near East University, North Cyprus. The co-author of this article is the supervisor of the dissertation.

\section{Competing interests}

The authors declare that no competing interests exist.

\section{Author's contributions}

Both the authors contributed equally to the theoretical development, analysis, interpretation and writing of the manuscript.

\section{Funding information}

This research received no specific grant from any funding agency in the public, commercial or not-for-profit sectors. 


\section{Data availability statement}

The data that support the findings of the study are available from the corresponding author, K.C., upon reasonable request.

\section{Disclaimer}

The views and opinions expressed in this article are those of the authors and do not necessarily reflect the official policy or position of any affiliated agency of the authors.

\section{References}

Aberson, C.L., Healy, M., \& Romero, V. (2000). Ingroup bias and self-esteem: A metaanalysis. Personality and Social Psychology Review, 4(2), 157-173. https://doi. org/10.1207/S15327957PSPR0402_04

Aguinis, H., \& Glavas, A. (2013). Embedded versus peripheral corporate social responsibility: Psychological foundations. Industrial and Organizationa Psychology, 6(4), 314-332. https://doi.org/10.1111/iops.12059

Aizenman, J., Chinn, M.D., \& Ito, H. (2010). The financial crisis, rethinking of the global financial architecture and the trilemma. Asian Development Bank Institute Working Paper Series, 213(April), 1-30. https://doi.org/10.2139/ssrn.1592810

Albert, S., \& Whetten, D.A. (1985). Organizational identity. Research in Organizationa Behavior, 7, 263-295.

Ali, U., \& Waqar, S. (2013). Teachers' organizational citizenship behaviour working under different leadership styles. Pakistan Journal of Psychological Research, 28(2), 297-316.

Armstrong, J.S., \& Overton, T.S. (1977). Estimating nonresponse bias in mail surveys. Journal of Marketing Research, 14(3), 396-402. https://doi.org/10.1177/ 002224377701400320

Ashforth, B.E., Harrison, S.H., \& Corley, K.G. (2008). Identification in organizations: An examination of four fundamental questions. Journal of Management, 34(3) 325-374. https://doi.org/10.1177/0149206308316059

Barakat, S.R., Isabella, G., Boaventura, J.M.G., \& Mazzon, J.A. (2016). The influence of corporate social responsibility on employee satisfaction. Management Decision 54(9), 2325-2339. https://doi.org/10.1108/MD-05-2016-0308

Bartels, J., Peters, O., Jong, M., Pruyn, A., \& Molen, M.V. (2010). Horizontal and vertical communication as determinants of professional and organisational identification Personnel Review, 39(2), 210-226. https://doi.org/10.1108/00483481011017426

Bauman, C.W., \& Skitka, L.J. (2012). Corporate social responsibility as a source of employee satisfaction. Research in Organizational Behaviour, 32, 63-86. https:// doi.org/10.1016/j.riob.2012.11.002

Bhattacharya, C.B., Korschun, D., \& Sen, S. (2009). Strengthening stakeholdercompany relationships through mutually beneficial corporate social responsibility initiatives. Journal of Business Ethics, 85(2), 257-272. https://doi.org/10.1007/ s10551-008-9730-3

Blau, P.M. (1964). Justice in social exchange. Sociological Inquiry, 34(2), 193-206 https://doi.org/10.1111/j.1475-682X.1964.tb00583.x

Brammer, S., He, H., \& Mellahi, K. (2015). Corporate social responsibility, employee organizational identification, and creative effort: The moderating impact of corporate ability. Group \& Organization Management, 40(3), 323-352. https:// corporate ability. Group \& Organization
doi.org/10.1177/1059601114562246

Brammer, S., Millington, A., \& Rayton, B. (2007). The contribution of corporate social responsibility to organizational commitment. The International Journal of Human Resource Management, 18(10), 1701-1719. https://doi.org/10.1080/0958519070 1570866

Caligiuri, P., Mencin, A., \& Jiang, K. (2013). Win-win-win: The influence of companysponsored volunteerism programs on employees, NGOs, and business units. Personnel Psychology, 66(4), 825-860. https://doi.org/10.1111/peps.12019

Carmeli, A., Gilat, G., \& Waldman, D.A. (2007). The role of perceived organizational performance in organizational identification, adjustment and job performance*. Journal of Management Studies, 44(6), 972-992. https://doi.org/10.1111/j.1467 6486.2007.00691.x

Chang, S.J., Van Witteloostuijn, A., \& Eden, L. (2010). From the editors: Common method variance in international business research. Journal of International method variance in international business research. Journal of Intern
Business Studies, 41(2), 178-184. https://doi.org/10.1057/jibs.2009.88

Chun, J.S., Shin, Y., Choi, J.N., \& Kim, M.S. (2013). How does corporate ethics contribute to firm financial performance?: The mediating role of collective organizational commitment and organizational citizenship behaviour. Journal of Management, 39(4), 853-877. https://doi.org/10.1177/0149206311419662

Chung, J., \& Monroe, G.S. (2003). Exploring social desirability bias. Journal of Business Ethics, 44(4), 291-302. https://doi.org/10.1023/A:1023648703356

Cropanzano, R., \& Rupp, D.E. (2008). Social exchange theory and organizational justice: Job performance, citizenship behaviours, multiple foci, and a historical integration of two literatures. In S.W. Gilliland, D.P. Skarlicki, \& D.D. Steiner (Eds.), Research in social issues in management: Justice, morality, and social (pp. 63-99). Greenwich: Information Age Publishing.

De Roeck, K.D., Marique, G., Stinglhamber, F., \& Swaen, V. (2014). Understanding employees' responses to corporate social responsibility: Mediating roles of overall justice and organisational identification. The International Journal of Human Resource Management, 25(1), 91-112. https://doi.org/10.1080/0958519 2.2013.781528
DiPaola, M.F., \& Hoy, W.K. (2005). School characteristics that foster organizational citizenship behavior. Journal of School Leadership, 15(4), 387-406. https://doi. org/10.1177/105268460501500402

Eisenberger, R., Armeli, S., Rexwinkel, B., Lynch, P.D., \& Rhoades, L. (2001). Reciprocation of perceived organizational support. Journal of Applied Psychology, 86(1), 42-51. https://doi.org/10.1037/0021-9010.86.1.42

El Akremi, A., Gond, J.P., Swaen, V., De Roeck, K., \& Igalens, J. (2015). How do employees perceive corporate responsibility? Development and validation of a multidimensional corporate stakeholder responsibility scale. Journal of Management, 44(2), 619-657. https://doi.org/10.1177/0149206315569311

Evans, W.R., \& Davis, W. (2014). Corporate citizenship and the employee: An organizational identification perspective. Human Performance, 27(2), 129-146. https://doi.org/10.1080/08959285.2014.882926

Evans, W.R., Goodman, J.M., \& Davis, W.D. (2010). The impact of perceived corporate citizenship on organizational cynicism, OCB, and employee deviance. Human Performance, 24(1), 79-97. https://doi.org/10.1080/08959285.2010.530632

Farooq, O., Payaud, M., Merunka, D., \& Florence, V.P. (2014). The impact of corporate social responsibility on organizational commitment: Exploring multiple mediation mechanisms. Journal of Business Ethics, 125(4), 563-580. https://doi.org/10.1007/ s10551-013-1928-3

Farooq, O., Rupp, D.E., \& Farooq, M. (2016). The multiple pathways through which internal and external corporate social responsibility influence organizational identification and multifoci outcomes: The moderating role of cultural and social orientations. Academy of Management Journal, 60(3), 954-985. https://doi.org/ 10.5465/amj.2014.0849

Fombrun, C.J. (2005). A world of reputation research, analysis and thinking-building corporate reputation through CSR initiatives: Evolving standards. Corporate Reputation Review, 8(1), 7-12. https://doi.org/10.1057/palgrave.crr.1540235

Geckil, T., \& Tikici, M. (2015). A study on developing the organizational democracy scale. Ammeidaresi Dergisi, 48(4), 41-78.

Gergen, K.J. (1969). The psychology of behavior exchange. Oxford: Addison-Wesley.

Glavas, A., \& Godwin, L. (2013). Is the perception of 'goodness' good enough? Exploring the relationship between perceived corporate social responsibility and employee organizational identification. Journal of Business Ethics, 114(1), 15-27.

Gond, J.P., Kang, N., \& Moon, J. (2011). The government of self-regulation: On the comparative dynamics of corporate social responsibility. Economy and Society, 40(4), 640-671. https://doi.org/10.1080/03085147.2011.607364

Graafland, J., \& Zhang, L. (2014). Corporate social responsibility in China: Implementation and challenges. Business Ethics: A European Review, 23(1), 34-49. https://doi.org/ 10.1111/beer.12036

Graham, J.W. (1991). An essay on organizational citizenship behaviour. Employee Responsibilities and Rights Journal, 4(4), 249-270. https://doi.org/10.1007/ BF01385031

Greening, D.W., \& Turban, D.B. (2000). Corporate social performance as a competitive advantage in attracting a quality workforce. Business \& Society, 39(3), 254-280. https://doi.org/10.1177/000765030003900302

Gruenberg, B. (1980). The happy worker: An analysis of educational and occupational differences in determinants of job satisfaction. American Journal of Sociology, 86 247-271. https://doi.org/10.1086/227238

Hair, J.F., Black, W.C., Babin, B.J., \& Anderson, R.E. (2014). Multivariate data analysis (7th edn., Pearson new internat. ed.). Harlow: Pearson.

Hameed, I., Riaz, Z., Arain, G.A., \& Farooq, O. (2016). How do internal and external CSR affect employees' organizational identification? A perspective from the group engagement model. Frontiers in Psychology, 7, 788. https://doi.org/10.3389/fpsyg. 2016.00788

Handelman, J.M. (2006). Corporate identity and the societal constituent. Journal of the Academy of Marketing Science, 34(2), 107-114. https://doi.org/10.1177/ 0092070305284970

Hansen, S.D., Dunford, B.B., Boss, A.D., Boss, R.W., \& Angermeier, I. (2011). Corporate social responsibility and the benefits of employee trust: A cross-disciplinary perspective. Journal of Business Ethics, 102(1), 29-45. https://doi.org/10.1007/ s10551-011-0903-0

He, H., \& Brown, A.D. (2013). Organizational identity and organizational identification: A review of the literature and suggestions for future research. Group \& Organization Management, 38(1), 3-35. https://doi.org/10.1177/1059601112473815

Hofman, P.S., \& Newman, A. (2014). The impact of perceived corporate social responsibility on organizational commitment and the moderating role of collectivism and masculinity: Evidence from China. The International Journal of Human Resource Management, 25(5), 631-652. https://doi.org/10.1080/09585192.2013. 792861

Hu, L., \& Bentler, P.M. (1999). Cut-off criteria for fit indexes in covariance structure analysis: Conventional criteria versus new alternatives. Structural Equation Modeling: A Multidisciplinary Journal, 6(1), 1-55. https://doi.org/10.1080/ 10705519909540118

Idemudia, U. (2011). Corporate social responsibility and developing countries: Moving the critical CSR research agenda in Africa forward. Progress in Development Studies, 11(1), 1-18. https://doi.org/10.1177/146499341001100101

Jamali, D., \& Karam, C. (2018). Corporate social responsibility in developing countries as an emerging field of study. International Journal of Management Reviews, 20(1), 32-61. https://doi.org/10.1111/ijmr.12112

Jiang, K., Lepak, D.P., Hu, J., \& Baer, J.C. (2012). How does human resource management influence organizational outcomes? A meta-analytic investigation of mediating mechanisms. Academy of Management Journal, 55(6), 1264-1294. https://doi.org/10.5465/amj.2011.0088 
Jones, D.A. (2010). Does serving the community also serve the company? Using organizational identification and social exchange theories to understand employee responses to a volunteerism programme. Journal of Occupational and employee responses to a volunteerism programme. Journal of Occupational and
Organizational Psychology, 83(4), 857-878. https://doi.org/10.1348/096317909 Organiza
$\mathrm{X} 477495$

Jones, D.A., \& Rupp, D.E. (2016). Social responsibility in and of organizations: The psychology of corporate social responsibility among organizational members. In N. Andersons, D.S. Ones, H.K. Sinangil, \& C. Viswesvaran (Eds.), Handbook of industrial, work, and organizational psychology (2nd edn., pp. 333-348). Thousand industrial, work,
Oaks, CA: Sage.

Karaköse, T. (2007). High school teachers' perceptions regarding principals' ethical leadership in Turkey. Asia Pacific Education Review, 8(3), 464-477. https://doi. org/10.1007/BF03026474

Konovsky, M.A., \& Organ, D.W. (1996). Dispositional and contextual determinants of organizational citizenship behaviour. Journal of Organizational Behavior, 17(3) 253-266. https://doi.org/10.1002/(SICI)1099-1379(199605)17:3<253::AID-JOB747> 3.0.CO;2-Q

Kunda, M.M., Ataman, G., \& Behram, N.K. (2019). Corporate social responsibility and organizational citizenship behaviour: The mediating role of job satisfaction. Journal of Global Responsibility, 10(1), 47-68. https://doi.org/10.1108/JGR-062018-0018

Locke, E.A. (1969). What is job satisfaction? Organizational Behaviour and Human Performance, 4(4), 309-336. https://doi.org/10.1016/0030-5073(69)90013-0

Macdonald, S., \& MacIntyre, P. (1997). The generic job satisfaction scale: Scale development and its correlates. Employee Assistance Quarterly, 13(2), 1-16. https://doi.org/10.1300/J022v13n02_01

Mael, F., \& Ashforth, B.E. (1992). Alumni and their alma mater: A partial test of the reformulated model of organizational identification. Journal of Organizational Behavior, 13(2), 103-123. https://doi.org/10.1002/job.4030130202

Markus, H.R., \& Kitayama, S. (1991). Culture and the self: Implications for cognition, emotion, and motivation. Psychological Review, 98(2), 224-253. https://doi. org/10.1037/0033-295X.98.2.224

McWilliams, A., Siegel, D.S., \& Wright, P.M. (2006). Corporate social responsibility: Strategic implications*. Journal of Management Studies, 43(1), 1-18. https://doi. org/10.1111/j.1467-6486.2006.00580.

Onkila, T. (2015). Pride or embarrassment? Employees' emotions and corporate socia responsibility. Corporate Social Responsibility and Environmental Management 22(4), 222-236. https://doi.org/10.1002/csr.1340

Oplatka, I. (2006). Going beyond role expectations: Toward an understanding of the determinants and components of teacher organizational citizenship behaviour. Edu cational Administration Quarterly, 42(3), 385-423. https://doi.org/10.1177/ $0013161 \times 05285987$

Organ, D.W. (1988). Organizational citizenship behaviour: The good soldier syndrome. Lexington, MA: Lexington Books/D.C. Heath and Com.

Organ, D.W., \& Ryan, K. (1995). A meta-analytic review of attitudinal and dispositional predictors of organizational citizenship behaviour. Personnel Psychology, 48(4), 775-802. https://doi.org/10.1111/j.1744-6570.1995.tb01781.x

Organ, D.W., Podsakoff, P.M., \& MacKenzie, S.B. (2006). Organizational citizenship behavior. Its nature, antecedents, and consequences. Thousand Oaks, CA: Sage.

Orlitzky, M. (2005). Payoffs to social and environmental performance. The Journal of Investing, 14(3), 48-52. https://doi.org/10.3905/joi.2005.580548

Petersitzke, M. (2009). Supervisor psychological contract management. Wiesbaden Gabler GWV Fachverlage.

Podsakoff, N.P., Podsakoff, P.M., MacKenzie, S.B., Maynes, T.D., \& Spoelma, T.M. (2014). Consequences of unit-level organizational citizenship behaviours: A review and recommendations for future research. Journal of Organizational Behaviour, 35(S1) S87-S119. https://doi.org/10.1002/job.1911

Podsakoff, P.M., MacKenzie, S.B., Lee, J.-Y., \& Podsakoff, N.P. (2003). Common method biases in behavioural research: A critical review of the literature and recommended remedies. Journal of Applied Psychology, 88(5), 879-903. https://doi.org/10.1037/ 0021-9010.88.5.879

Podsakoff, P.M., MacKenzie, S.B., Moorman, R.H., \& Fetter, R. (1990). Transformational leader behaviours and their effects on followers' trust in leader, satisfaction, and organizational citizenship behaviours. The Leadership Quarterly, 1(2), 107-142. organizational citizenship behaviours. The Lead
https://doi.org/10.1016/1048-9843(90)90009-7

Podsakoff, P.M., MacKenzie, S.B., \& Podsakoff, N.P. (2011). Sources of method bias in social science research and recommendations on how to control it. Annual Review of Psychology, 63(1), 539-569. https://doi.org/10.1146/annurev-psych-120710100452

Raykov, T., \& Marcoulides, G.A. (1999). On desirability of parsimony in structural equation model selection. Structural Equation Modelling, 6(3), 292-300. https:// doi.org/10.1080/10705519909540135
Rupp, D.E., Ganapathi, J., Aguilera, R.V., \& Williams, C.A. (2006). Employee reactions to corporate social responsibility: An organizational justice framework. Journal of Organizational Behavior, 27(4), 537-543. https://doi.org/10.1002/job.380

Rupp, D.E., \& Mallory, D.B. (2015). Corporate social responsibility: Psychological, person-centric, and progressing. Annual Review of Organizational Psychology and Organizational Behaviour, 2(1), 211-236. https://doi.org/10.1146/annurevorgpsych-032414-111505

Rupp, D.E., Shao, R., Thornton, M.A., \& Skarlicki, D.P. (2013). Applicants' and employees' reactions to corporate social responsibility: The moderating effects of first-party justice perceptions and moral identity. Personnel Psychology, 66(4), first-party justice perceptions and moral iden

Sarfraz, M., Qun, W., Abdullah, M.I., \& Alvi, A.T. (2018). Employees' perception of corporate social responsibility impact on employee outcomes: Mediating role of organizational justice for small and medium enterprises (SMEs). Sustainability, 10(7), 2429. https://doi.org/10.3390/su10072429

Sesen, H., \& Basim, N.H. (2012). Impact of satisfaction and commitment on teachers' organizational citizenship. Educational Psychology, 32(4), 475-491. https://doi.or $\mathrm{g} / 10.1080 / 01443410.2012 .670900$

Shapira-Lishchinsky, O., \& Rosenblatt, Z. (2010). School ethical climate and teachers' voluntary absence. Journal of Educational Administration, 48(2), 164-181. https://doi.org/10.1108/09578231011027833

Sharma, E. (2019). A review of corporate social responsibility in developed and developing nations. Corporate Social Responsibility and Environmental Management, 26(4), 712-720. https://doi.org/10.1002/csr.1739

Shen, J., \& Benson, J. (2016). When CSR is a social norm: How socially responsible human resource management affects employee work behaviour. Journal of Management, 42(6), 1723-1746. https://doi.org/10.1177/0149206314522300

Snider, J., Hill, R.P., \& Martin, D. (2003). Corporate social responsibility in the 21st century: A view from the world's most successful firms. Journal of Business Ethics, 48(2), 175-187. https://doi.org/10.1023/B:BUSI.0000004606.29523.db

Somech, A., \& Bogler, R. (2005). Organizational citizenship behaviour in school: How does it relate to participation in decision making? Journal of Educationa Administration, 43(5), 420-438. https://doi.org/10.1108/09578230510615215

Stites, J.P., \& Michael, J.H. (2011). Organizational commitment in manufacturing employees: Relationships with corporate social performance. Business \& Society, 50(1), 50-70. https://doi.org/10.1177/0007650310394311

Turan, S. (2002). Organizational climate and organizational commitment: A study of human interactions in Turkish public schools. Educational Planning, 14(2), 20-30.

Turker, D. (2009). Measuring corporate social responsibility: A scale development study. Journal of Business Ethics, 85(4), 411-427. https://doi.org/10.1007/s10551 008-9780-6

Tyler, T.R., \& Blader, S.L. (2003). The group engagement model: Procedural justice, social identity, and cooperative behavior. Personality and Social Psychology Review, 7(4), 349-361. https://doi.org/10.1207/S15327957PSPR0704_07

Valentine, S., \& Barnett, T. (2003). Ethics code awareness, perceived ethical values, and organizational commitment. Journal of Personal Selling \& Sales Management and organizational commitment. Journal of Personal Selling \& Sales Mar

Valentine, S., \& Fleischman, G. (2008). Ethics programs, perceived corporate social responsibility and job satisfaction. Journal of Business Ethics, 77(2), 159-172. responsibility and job satisfaction. Journal
https://doi.org/10.1007/s10551-006-9306-z

Wang, H., Tong, L., Takeuchi, R., \& George, G. (2016). Corporate social responsibility: An overview and new research directions. Academy of Management Journal, 59(2), 534-544. https://doi.org/10.5465/amj.2016.5001

Wang, W., Fu, Y., Qiu, H., Moore, J.H., \& Wang, Z. (2017). Corporate social responsibility and employee outcomes: A moderated mediation model of organizational identification and moral identity. Frontiers in Psychology, 8, 1906. https://doi. org/10.3389/fpsyg.2017.01906

Williams, L.J., \& Anderson, S.E. (1991). Job satisfaction and organizational commitment as predictors of organizational citizenship and in-role behaviours. Journal of Management, 17(3), 601-617. https://doi.org/10.1177/01492063910 1700305

Wu, C.-H., Liu, J., Kwan, H.K., \& Lee, C. (2016). Why and when workplace ostracism inhibits organizational citizenship behaviours: An organizational identification perspective. The Journal of Applied Psychology, 101(3), 362-378. https://doi. org/10.1037/apl0000063

Zeinabadi, H., \& Salehi, K. (2011). Role of procedural justice, trust, job satisfaction, and organizational commitment in organizational citizenship behaviour (OCB) of teachers: Proposing a modified social exchange model. Procedia - Social and Behavioural Sciences, 29, 1472-1481. https://doi.org/10.1016/j.sbspro.2011. 11.387 